Библиографија / Bibliography

Срђан Р. Петровић*

Универзитет у Београду

Филолошки факултет

Катедра за славистику
УДК

013:378.245(497.11):[811.161.1"1960/2015"

ДОИ

https://doi.org/10.18485/analiff.2016.28.1.21

\title{
БИБЛИОГРАФИЈА МАГИСТАРСКИХ РАДОВА О РУСКОМ ЈЕЗИКУ ОДБРАҢЕНИХ НА ФИЛОЛОШКОМ ФАКУЛТЕТУ УНИВЕРЗИТЕТА У БЕОГРАДУ ОД 1960. ДО 2015. ГОДИНЕ
}

Постдипломске студије, независно од комплекса наука које се у њеном центру на-лазе, представљају један од најзначајнијих периода за конституисање научноистражи-вачке мисли и потенцијала сваке земље. Студије филологије у том погледу нису изузе-так. Постдипломци током студија виших степена подробније и свеобухватније проничу у области које ће бити предмет њихове уже специјалности, а један од начина за сти-цање кумулативног увида у истраживачку тематику и добијене резултате у том погледу могу представљати библиографије.

Циљ овог прилога јесте пружање целовитог прегледа у магистарске радове из области науке о руском језику ${ }^{1}$ одбрањене на Филолошком факултету Универзитета у Београду. Почетни оквир представља 1960. година, када је Филолошки факултет постао засебна и самостална високошколска институција. Како су на основу члана 29 Закона о изменама о допунама Закона и високом образовању (Закон 2010: 10-11) и члана 165 Статута Универзитета у Београду (Статут 2011: 104-105) закључно са 30. септембром 2014. године одбрањени и последњи магистарски радови према старом систему студија на Универзитету у Београду, магистарски радови у овој библиографији могу се сма-трати описаним у целости. Подаци које ћемо предочити проверени су и усклађени са званичном документацијом Центра за постдипломске студије Филолошког факултета Универзитета у Београду.

*_srdjan09@mail.ru

1 Наука о руском језику поима се у ужем смислу, стога су из библиографије изузети магистарски радови из области методике наставе руског језика. Њихов преглед и комплетан библиографски опис за период до 2015. године в. у: Петрович, 2015. 
Магистарски радови су наведени према хронолошком критеријуму на основу године одбране. Допунски податак унет је у библиографски опис искључиво у случаје-вима када се година одбране разликовала од године наведене на самој публикацији. У грађу смо уврстили магистарске радове који у целости или конфронтативно расветља-вају неко од релевантних подручја науке о руском језику. У циљу достизања вишег степена прегледности након библиографског описа налази се и предметни регистар.

1969.

1. ЦВЕТКОВИЋ, Десанка

Једночлане реченице у руском и српскохрватском језику / Десанка Цветковић. - 208 листова.

1972.

2. АНЂЕЛКОВИЋ, Ивана

Разлике у употреби глаголског вида у руском и српскохрватском језику / Ивана Анђелковић. - 214 листова.

Одбрањен 1973.

3. ВОЈНОВИЋ, Олга

Безличне реченице у руском језику у поређењу са истим реченицама у српскохр-ватском језику / Олга Војновић. - 61 лист.

1974.

4. КАРАНФИЛОВСКИ, Максим

Изражавање прошлог времена у руском и македонском језику : како се преводи руско прошло време на македонски језик / Максим Каранфиловски. - 117 листова.

1976.

5. АЛЕКСИЋ, Богданка

Слоговни сонанти у руском и српскохрватском језику на материјалу речника про-фесора Радована Кошутића уз „Руске примере“ / Богданка Алексић. - 118 листова.

6. ВЛАТКОВИЋ, Драгица

Сложенице у поемама В. В. Мајаковског / Драгица Влатковић. 
БИБЛИОГРАФИЈА МАГИСТАРСКИХ РАДОВА О РУСКОМ ЈЕЗИКУ ОДБРАҢЕНИХ НА ФИЛОЛОШКОМ ФАКУЛТЕТУ УНИВЕРЗИТЕТА У БЕОГРАДУ ОД 1960. ДО 2015. Г.

-43 листа.

Одбрањен 1977.

7. МАРОЈЕВИЋ, Милена

Значење и употреба кратког и дугог придевског облика у предикативној функци-ји у руском језику у поређењу са српскохрватским / Милена Маројевић. - 98 ли-стова.

8. МЕДВЕДЕВ, Никола

Идиомски изрази у језику А. П. Чехова : на материјалу приповедака од средине 80-тих година / Никола Медведев. - $109+379$ листова.

1979.

9. АЛАБУРИЋ, Јелица

Значење инструментала у руском и српскохрватском језику на материјалу народ-них бајки / Јелица Алабурић. - 108 листова.

10. МИЛИНКОВИЋ, Љубо

Изражавање временских односа у руском и српскохрватском језику предлошко- -падежним конструкцијама / Љубо Р. Милинковић. - 137 листова.

1980.

11. ЋИРКОВИЋ, Милорад

Инфинитивске конструкције у руском и српскохрватском књижевном језику : Је-зик књижевних дела / Милорад Ћирковић. - 160 листова.

Одбрањен 1981.

12. СТОЈАНОВИЋ, Андреј

Нека питања фонолошке и морфолошке адаптације руских топонима у српскохр-ватском језику / Андреј Стојановић. - 235 листова.

1981.

13. БОГДАНОВИЋ, Стојче

Род именица са значењем лица у руском и српскохрватском језику / Стојче Богда-новић. - 106 листова.

Одбрањен 1983. 
1982.

14. СТЕВАНОВИЋ, Милун

Именице са хипокористичким суфиксима у руском језику и начини њихове тран-спозиције на српскохрватски језик / Милун Стевановић. - 92 листа.

Одбрањен 1983.

1983.

15. МУШОВИЋ, Абдулах

Изражавање временских односа прилошким изразима у савременом руском и сав-ременом српскохрватском језику / Абдулах Мушовић. - 86 листова.

16. ПОЈАТИЋ, Дурија

Економско-политичка терминологија и лексика у Лењиновом делу и проблеми њиховог превођења на српскохрватски језик : на материјалу изабраног корпуса Лењинових текстова и објављених српскохрватских превода / Дурија Појатић. - 158 листова.

17. ТРАЈКОВИЋ, Живојин

Прилози са суфиксима субјективне оцене у руском и њихови српскохрватски еквиваленти / Живојин Трајковић. - 94 листа.

1984.

18. ЧАМПАР, Драгован

Именички аугментативи у руском и српскохрватском језику / Драгован Чампар. - 242 листа.

1986

19. БОШКОВИЋ, Бошко

Именице pluralia tantum у руском и српскохрватском језику / Бошко Бошковић. - 76 листова.

20. ШЕВО, Александар

Лексичка спојивост кретања у руском језику у поређењу са српскохрватским : на лексикографском материјалу / Александар Шево. - 106 листова.

1987.

21. КАТНИЋ, Марина 
БИБЛИОГРАФИЈА МАГИСТАРСКИХ РАДОВА О РУСКОМ ЈЕЗИКУ ОДБРАњЕНИХ НА ФИЛОЛОШКОМ ФАКУЛТЕТУ УНИВЕРЗИТЕТА У БЕОГРАДУ ОД 1960. ДО 2015. Г.

Категорија лица у књижевноуметничком и публицистичком стилу руског и срп-скохрватског језика / Марина Катнић. - 137 листова.

22. ТРАЈКОВИЋ, Радован

Упитне реченице у руском и српскохрватском језику / Радован Трајковић. - 102 листа.

1989.

23. КОНДИЋ, Снежана

Придјеви изведени префиксима страног поријекла са негативним значењем у сав-ременом српскохрватском, пољском и руском језику / Снежана Кондић. - 126 ли-стова.

24. СТАНКОВИЋ, Бранка

Руска терминологија у области васпитања и образовања и српскохрватски еквива-ленти / Бранка Станковић. - 91 лист.

1991.

25. БЕЛОКАПИЋ, Вера

Савремена економска терминологија у руском и српскохрватском језику / Вера Белокапић. - 120 листова.

26. ДАМљАНОВИЋ, Дара

Исказивање реципрочности у руском и српскохрватском језику / Дара Дамљано-вић. - 119 листова.

Одбрањен 1992.

27. МИРКОВ ВУКОВИЋ, Милутин

Начин изражавања заповијести у руском и српскохрватском језику / Милутин Мирков Вуковић. - 226 листова.

Одбрањен 1992.

28. ПОПОВИЋ, Људмила

Семантички потенцијал назива за боје у руском, украјинском и српскохрватском језику : на материјалу фолклора XIX века / Људмила Поповић. - 158 листова.

1992.

29. МИЛЕНКОВИЋ, Андријана М.

Лексичко-граматички проблеми превођења научне и стручне литературе са руског на српски језик / Андријана М. Миленковић. - 
147 листова.

Одбрањен 1993.

30. ПАНТЕЛИЋ МЛАДЕНОВИЋ, Јелена

Партикуларизатори у савременом руском језику у поређењу са српскохрватским на примерима из књижевних текстова / Јелена Пантелић-Младеновић. - 105 ли-стова.

Одбрањен 1993.

31. РЕЉИЋ, Митра

Социолингвистичка утемељеност, стилистичка вредност и могућност превођења руских неологизама из 80-тих година / Митра Рељић. - 216 листова.

Одбрањен 1994.

1993.

32. ПЕТРОВИЋ, Марија

Категорија аниматности / инаниматности у савременом руском и српскохрват-ском књижевном језику / Марија Ј. Петровић. - 120 листова.

Одбрањен 1994.

33. ПРИЈИЋ НИСЕТЕО, Ивана

Фразеолошки проблеми превођења с руског језика на српски / Ивана С. Пријић-Нисетео. - 243 листа.

Одбрањен 1994.

1994.

34. СТОЈКОВИЋ, Смиљка

Синтагматске особености руског језика у области пословног дописивања и про-блеми превођења на српски језик / Смиљка Стојковић. - 148 листова.

1996.

35. АЈДУКОВИЋ, Јован

Речи са лексикографском напоменом ,русизам“ у речницима савременог српско-хрватског књижевног језика / Јован Ајдуковић. 303 листа.

36. ВАСИЋ, Саша 
БИБЛИОГРАФИЈА МАГИСТАРСКИХ РАДОВА О РУСКОМ ЈЕЗИКУ ОДБРАҢЕНИХ НА ФИЛОЛОШКОМ ФАКУЛТЕТУ УНИВЕРЗИТЕТА У БЕОГРАДУ ОД 1960. ДО 2015. Г.

Лексичка антонимија у руским пословицама / Саша Васић. 163 листа.

Одбрањен 1997.

37. КЕРКЕЗ, Драгана

Беспредлошки перифрастични предикати са семикопулативним глаголима у сав-ременом руском језику у поређењу са српским / Драгана Керкез. - 198 листова.

Одбрањен 1997.

1998.

38. МИХАЈЛОВИЋ, Јелена

Именска рекција у руском и српском језику / Јелена Михајловић. - 167 листова.

2001.

39. ВИЋЕНТИЋ, Биљана

Карактеристике синтаксе у прозним делима Људмиле Петрушевске / Биљана Ви-ћентић. - 115 листова.

40. ТЕРЗИЋ, Светлана

Nomina agentis са суфиксом -ац и његовим дериватима у српском језику и њихо-ви руски еквиваленти / Светлана В. Терзић. - 189 листова.

41. ТРНАВАЦ, Радослава

Концепт „наде“ у савременом руском и српском језику / $\mathrm{Pa}$ дослава М. Трнавац. - 131 лист.

2003.

42. ВУЈИСИЋ, Благоје

Неодређеноличне и уопштеноличне реченице у руском језику у поређењу са срп-ским : на материјалу „Живих и мртвих“К. Симонова и „Пролома“ Б. Ћопића / Благоје Вујисић. - 161 лист.

Одбрањен 2004.

2005.

43. ПЕЈАНОВИЋ, Ана

Устаљена поређења човјек - предмет као лингвокултуролошке јединице у руском и српском језику / Ана Пејановић. - 110 листова. 
2006.

44. ГИНИЋ, Јелена

Промене у нормативној фонетици савременог руског књижевног језика / Јелена Гинић. - 261 лист.

2007.

45. БАБИЋ, Здравко

Имперсоналност у савременом руском, пољском и српском језику / Здравко Ба-бић. - 201 листова.

46. ГАЕВ, Тања

Семантика бројева у руском, украјинском и српском језику : на материјалу фол-клора XIX века / Тања Гаев. - 166 листова.

47. ЂАПА ИВЕТИЋ, Вукосава

Терминологија у билатералним официјелним документима на српском и руском језику / Вукосава Ђапа-Иветић. - 262 листа.

2008.

48. РАДОЈЧИЋ, Ружица

Категорија теличности у руском језику у поређењу са српским / Ружица Д. Радојчић. - 201 лист.

Одбрањен 2009.

2009.

49. ВЕЉКОВИЋ, Маја

Посесивне реченице у руском језику и њихови еквиваленти у српском / Маја 3. Вељковић. - 152 листа.

Одбрањен 2010.

50. ЛЕПОЈЕВИЋ, Јелена

Двотематске творенице у руском језику и њихови српски еквиваленти / Јелена Ле-појевић. - 162 стр.

Одбрањен 2010.

51. ПАВЛОВИЋ ШАЈТИНАЦ, Маја

Русизми у извештајима новинских извештача / Маја В. Павловић-Шајтинац. - 173 листа. 
БИБЛИОГРАФИЈА МАГИСТАРСКИХ РАДОВА О РУСКОМ ЈЕЗИКУ ОДБРАҢЕНИХ НА ФИЛОЛОШКОМ ФАКУЛТЕТУ УНИВЕРЗИТЕТА У БЕОГРАДУ ОД 1960. ДО 2015. Г.

\section{ПРЕДМЕТНИ РЕГИСТАР}

\begin{tabular}{|c|c|}
\hline Фонейика и фонолоїија & $5,12,44$ \\
\hline 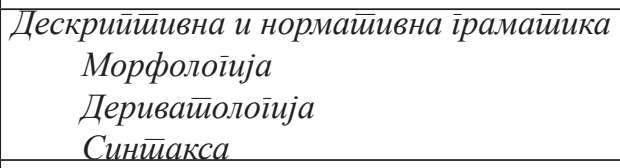 & $\begin{array}{l}2,12,13,19 \\
6,14,17,18,23,40,50 \\
1,3,7,9,11,22,30,34,37,38,39,42,49\end{array}$ \\
\hline Функиионална іррамайика & $4,9,10,15,21,26,27,32,45,48$ \\
\hline $\begin{array}{l}\text { Лексиколоїија и лексикоїрафија } \\
\text { Терминолойија }\end{array}$ & $\begin{array}{l}20,28,31,35,36,51 \\
16,24,25,47\end{array}$ \\
\hline Семанйика & 28,46 \\
\hline Фразеолоймја & $8,33,43$ \\
\hline Паремиолойија & 36 \\
\hline Сииилисиика & $21,29,31,34,39,51$ \\
\hline Нормаииивистиика & 12,44 \\
\hline 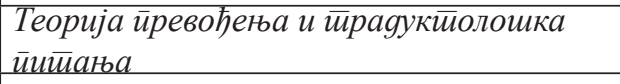 & $4,16,29,31,33,34,51$ \\
\hline Коїнийивна линївисииика & 41 \\
\hline Лині̄вокулииуролойија & 43 \\
\hline
\end{tabular}

\section{Литература}

Закон о изменама и допунама Закона о високом образовању // Службени гласник Републике Србије бр. 44 од 30.06.2010. године.

Петрович, С. (2015). Библиография кандидатских диссертаций по методике пре-подавания русского языка, защищённых на филологическом факультете Белградского университета, Русский язык как инославянский, 7, 253-258.

Статут Универзитета у Београду : Пречишћени текст. Београд: Гласник Универзи-тета у Београду, 2011, 162. 